\title{
Preliminary Investigation of the Corrosion Behavior of Proprietary Micro-alloyed Steels in Aerated and Deaerated Brine Solutions
}

\author{
Lawrence Onyeji iD and Girish Kale
}

\author{
(Submitted June 28, 2017; in revised form September 7, 2017; published online October 27, 2017)
}

\begin{abstract}
The corrosion performance of fairly new generation of micro-alloyed steels was compared in different concentrations of aerated and deaerated brines. Electrochemical polarization, weight loss and surface analyses techniques were employed. The results showed a threshold of corrosion rate at $3.5 \mathrm{wt}$.\% $\mathrm{NaCl}$ in both aerated and deaerated solutions. The average corrosion current density for steel $B$, for example, increased from $1.3 \mu \mathrm{A} \mathrm{cm}^{-2}$ in $1 \mathrm{wt} \% \mathrm{NaCl}$ to $1.5 \mu \mathrm{A} \mathrm{cm}$ in $3.5 \mathrm{wt} \% \% \mathrm{NaCl}$, but decreased to $1.4 \mu \mathrm{A} \mathrm{cm}{ }^{-2}$ in 10 wt. \% deaerated $\mathrm{NaCl}$ solutions. The aerated solutions exhibited an average of over $80 \%$ increase in corrosion current density in the respective concentrations when compared with the deaerated solution. These results can be attributed to the effects of dissolved oxygen (DO) which has a maximum solubility in $3.5 \mathrm{wt}$ \% $\mathrm{NaCl}$. DO as a depolarizer and electron acceptor in cathodic reactions accelerates anodic metal dissolution. The difference in carbon content and microstructures occasioned by thermomechanical treatment contributed to the witnessed variation in corrosion performance of the steels. Specifically, the results of the various corrosion techniques corroborated each other and showed that the corrosion rate of the micro-alloyed steels can be ranked as $\mathbf{C R}_{\text {Steel A }}<\mathrm{CR}_{\mathrm{X65}}<\mathrm{CR}_{\text {Steel B }}<\mathrm{CR}_{\text {Steel } \mathrm{C}}$.
\end{abstract}

Keywords aerated solutions, brine, corrosion behavior, deaerated solution, electrochemical techniques, micro-alloy steels

\section{Introduction}

Corrosion attack of oil and gas facilities is one of the greatest challenges to the operators in the industry. Therefore, assessing the impact of corrosion is of immediate concerns. The effects of corrosion if not controlled can affect production, cause economic loss and create ecological problems with the attendant security risks to life and properties (Ref 1,2). Crude oil and its products are mixtures of hydrocarbon which by themselves are not corrosive. However, they become corrosive in the presence of impurities and other components such as water, chloride salts, carbon dioxide $\left(\mathrm{CO}_{2}\right)$, hydrogen sulfide $\left(\mathrm{H}_{2} \mathrm{~S}\right)$, elemental sulfur, dissolved oxygen, organic acids and sulfate-reducing bacteria (SRB) (Ref 1, 3-5). Tremendous efforts have been made to mitigate and control the effects of corrosion. Some of these efforts have led to the development of various corrosion control techniques such as the use of composite materials (Ref 6, 7); various corrosion resistance steels (CRS) (Ref 8, 9), inhibitors (Ref 10), electrochemical protection (Ref 11, 12) and coating techniques (Ref 13-17). These techniques are either too expensive for effective deployment or too difficult to sustain and therefore have not adequately solved the problem of corrosion in the oil and gas industries. Choi et al. (Ref 18, 19) have proposed the

Lawrence Onyeji and Girish Kale, School of Chemical and Process Engineering, University of Leeds, Leeds LS2 9JT, UK. Contact e-mails: pmlio@leeds.ac.uk and G.M.Kale@leeds.ac.uk. development of new materials with high corrosion resistance at low cost as the most effective option to tackle the menace of corrosion in oil and gas industry.

Dissolved oxygen (DO) is one of the major corrosion enhancing components in crude oil. Liu et al. (Ref 1), Ismail and Adan (Ref 20) and Jung et al. (Ref 21) reported that the corrosion effect of dissolved oxygen is more prevalent than all other impurities present in crude oil. Liu et al. (Ref 1) studied the effects of chlorides, temperature, $\mathrm{pH}$, carbon dioxide $\left(\mathrm{CO}_{2}\right)$ and dissolved oxygen (DO) on the corrosion-induced leakage of the inner wall of crude oil pipeline. These studies showed that the effect of DO on the corrosion rate of the pipeline was dominant when compared with $\mathrm{CO}_{2}$ corrosion. Ismail and Adan (Ref 20) investigated the corrosion behavior of AISI 1040 steel in $\mathrm{NaCl}$ with different sulfate and chloride contents in the presence and absence of oxygen. The results revealed that the corrosion rate was higher in solutions containing oxygen than in all other deoxygenated solutions. Jung et al. (Ref 21) after an extensive laboratory experiments observed that the corrosion rates for galvanized steel pipe (GSP), carbon steel pipe (CSP) and ductile cast-iron pipe (DCIP) decreased to 72,75 and $91 \%$, respectively, when DO concentration was reduced from $9 \pm 0.5$ to $2 \pm 0.5 \mathrm{mg} / \mathrm{L}$. These results are in agreement with the reports of Islam and Farhat (Ref 22), Chilingar et al. (Ref 23) and Popoola et al. (Ref 24) that DO is a depolarizer and electron acceptor in cathodic reaction and therefore accelerates the anodic dissolution of metals. Also confirming this statement, Yari (Ref 2) reported that in a basic or neutral solution, oxygen reduction reaction in Eq 1 is the predominant cathodic reaction in competition with hydrogen evolution reaction of Eq 2.

Neutral/basic solutions: $\mathrm{O}_{2(\mathrm{~g})}+2 \mathrm{H}_{2} \mathrm{O}_{(\mathrm{l})}+4 \mathrm{e}^{-} \rightarrow 4 \mathrm{OH}_{(\mathrm{aq})}^{-}$ 
In hydrogen revolution : $2 \mathrm{H}_{(\mathrm{aq})}^{+}+2 \mathrm{e}^{-} \rightarrow \mathrm{H}_{2(\mathrm{~g})}$

The effect of DO on the corrosion of oil and gas facilities is significantly influenced by the presence of other components of crude oil streams such as chloride salts. According to researchers (Ref 2, 25-28), the concentration of chloride can influence the solubility of oxygen in produced water. Yari (Ref 2 ) specifically reported that the maximum oxygen concentration in seawater is obtained in $3.5 \mathrm{wt} . \% \mathrm{NaCl}$ solution. This work therefore is aimed at investigating the electrochemical behavior of three fairly new class of micro-alloyed steels, whose corrosion behavior has not been fully investigated, in different concentrations of aerated and deaerated brine solutions.

\section{Experimentals}

\subsection{Materials and Material Preparations}

Three micro-alloyed steels designated as Steel A, Steel B and Steel $\mathrm{C}$ with chemical compositions listed in Table 1 were used in this work. These steels which are meant for production of pipes are fairly new in the family of micro-alloyed steels, and their corrosion propensity has not been satisfactorily understood. A fourth material, API 5L X65 whose corrosion performance in different media has been investigated and adjudged as the most widely used pipeline material, was used as reference specimen (Ref 29-31). The specimens were wet grinded using MetaServ 250 Grinder-Polisher. Silicon carbide papers of different fineness up to P1200 grit were used. Each steel specimen after grinding was rinsed with distilled water, degreased with acetone, dried with compressed air and kept in a desiccator briefly until corrosion setup was ready. The specimens for OM and SEM/EDX analyses were further polished using 5,3 , and $1 \mu \mathrm{m}$ abrasive diamond slurry, degreased with acetone, rinsed with distilled water and dried with compressed air. The final polished surfaces were etched with $2 \%$ nital and analyzed using Zeiss AxioCam MRc 5 Optical Microscopy (OM) and Carl Zeiss EVO MA15 Scanning Electron Microscopy/Energy-Dispersed X-ray (SEM/EDAX).

\subsection{Experimental Setups and Conditions}

The experimental setup and conditions are summarized in Table 2. To ensure reproducibility, each of the four steels was polarized in triplicate using the parameters in Table 2. The anodic and cathodic branches of Tafel plots were conducted separately starting with the cathodic scan, followed by $15-\mathrm{min}$ open-circuit potential before the anodic sweep. This was to avoid surface alteration and electrolyte contamination as a result of iron dissolution during anodic sweep (Ref 32,33$)$. The guidelines in ASTM G102-89 (Ref 34) and Tait (Ref 35) were used to merge the branches. Tafel extrapolation technique was employed to extract Tafel corrosion parameters such as corrosion current density $\left(i_{\text {Corr }}\right)$, corrosion potentials $\left(E_{\text {Corr }}\right)$ and anodic $\left(\beta_{\mathrm{A}}\right)$ and cathodic $\left(\beta_{\mathrm{C}}\right)$ constants. The corrosion rate of the steels was calculated by inserting the values of corrosion current density $\left(i_{\text {Corr }}\right)$ obtained from Tafel extrapolation techniques in Eq 3

$\mathrm{CR}=\frac{3.27 \times 10^{-3} \times i_{\text {Corr }} \times E . W .}{\rho}$,

where $\mathrm{CR}=$ corrosion rate $\left(\mathrm{mm}\right.$ year $\left.^{-1}\right), i_{\text {Corr }}=$ corrosion current density $\left(\mu \mathrm{A} \mathrm{cm} \mathrm{cm}^{-2}\right), E . W .=$ equivalent weight $(\mathrm{g})$ and $\rho=$ density of the sample $\left(\mathrm{g} \mathrm{cm}^{-3}\right)$.

At the end of the polarization, the specimens were carefully removed from the cell, rinsed with deionized water and dried with nitrogen gas. Carl Zeiss EVO MA15 Scanning Electron Microscopy/Energy-Dispersed X-ray (SEM/EDAX) was used to characterize the corroded surfaces so as to identify their morphology and elemental composition.

\subsection{Weight Loss}

The corrosion rates of the steels were also assessed by weight loss technique. The steels were wet grinded up to P1200 grit with silicon carbide paper, washed with distilled water, ultrasonically cleaned in acetone for $4 \mathrm{~min}$ and dried in warm air. This was followed by careful measurements of the surface dimensions with which the surface area of the specimens were computed. The specimens were weighed using Adam PW124 analytical precision weighing balance, and the weight recorded as W1. Each of the three specimens were prepared. The specimens were then hung inside a beaker containing $3.5 \mathrm{wt} . \%$ $\mathrm{NaCl}$ at ambient temperature. One of the specimens was removed from the beaker after 24,48 and $72 \mathrm{~h}$, respectively. The corrosion products on the specimens were chemically cleaned in specific solution $(500 \mathrm{~mL}$ of $\mathrm{HCl}+500 \mathrm{~mL}$ of deionized water $+5 \mathrm{~g}$ of hexamethylenetetramine) with vigorous stirring for $10 \mathrm{~min}$, rinsed with deionized water, dried in warm air and reweighed $\left(W_{2}\right)$. The weight loss of the samples due to immersion for the respective time was then calculated as $\left(W_{1}-W_{2}\right)$, and the corrosion rate computed using Eq 4,

$\mathrm{CR}=\frac{8.76 \times 10^{4} \times\left(W_{1}-W_{2}\right)}{\rho \mathrm{At}}$,

where $\mathrm{CR}=$ corrosion rate $(\mathrm{mm} / \mathrm{year}), \rho=$ density $\left(\mathrm{g} / \mathrm{cm}^{3}\right)$, $A=$ surface are of the sample $\left(\mathrm{cm}^{2}\right)$ and $t=$ immersion time (hours).

\section{Results and Discussion}

\subsection{Microstructural Characteristics of the Samples}

The optical and SEM micrographs of the as-received steels are shown in Fig. 1 and 2, respectively. These figures show that

Table 1 Elemental specifications of the steels (\%)

\begin{tabular}{lllllllllllll}
\hline Steels & $\mathbf{C}$ & $\mathbf{S i}$ & $\mathbf{M n}$ & $\mathbf{P}$ & $\mathbf{S}$ & $\mathbf{C r}$ & $\mathbf{V}$ & $\mathbf{T i}$ & $\mathbf{N b}$ & $\mathbf{M o}$ & $\mathbf{C u}$ & $\mathbf{F e}$ \\
\hline A & 0.12 & 0.18 & 1.27 & 0.008 & 0.002 & 0.11 & 0.057 & 0.001 & 0.054 & 0.17 & 0.12 & Balance \\
B & 0.22 & 0.032 & 1.4 & 0.012 & 0.001 & 0.25 & 0.005 & 0.023 & 0.002 & 0.07 & 0.03 & Balance \\
B & 0.25 & 0.26 & 0.54 & 0.01 & 0.001 & 0.99 & 0.005 & 0.008 & 0.022 & 0.46 & 0.098 & Balance \\
X65 & 0.12 & 0.18 & 1.27 & 0.008 & 0.002 & 0.11 & 0.057 & 0.001 & 0.054 & 0.17 & 0.12 & Balance \\
\hline
\end{tabular}


Table 2 Experimental parameters and corrosion conditions

Description of items

Parameters

Electrode (working) materials

Counter electrode

Reference electrode

Working electrode surface area, $\mathrm{cm}^{2}$

Electrolytes, wt.\%

Corrosion cell

Electrolyte volume per test, $\mathrm{mL}$

Electrolyte environmental conditions

Test pressure, bar

Temperature, ${ }^{\circ} \mathrm{C}$

Solution $\mathrm{pH}$

Test period for LPR, $\mathrm{h}$

Potentiostat

Analytical software

Electrochemical measurements

LPR sweep range versus OCP, $\mathrm{mV}$

LPR sweep rate, $\mathrm{mV} / \mathrm{S}$

Tafel plot scan range, $\mathrm{mV}$

Tafel plot scan rate, $\mathrm{mV} / \mathrm{S}$
A, B, C and X65

Platinum mesh

Silver/silver chloride $(\mathrm{Ag} / \mathrm{AgCl})-(\mathrm{Sat} . \mathrm{KCl})$

1

$\mathrm{NaCl}: 1.0,3.5$, and 10.0

EG\&G princeton applied research model K0235 flat cell 250

Aerated and deaerated

1

Ambient

Unbuffered

6

Solartron analytical SI 1287 electrochemical interface Coreware and CoreView

Potentiodynamic polarization (LPR, Tafel Plot)

$\pm 15$

0.25

$\pm 250$

0.5
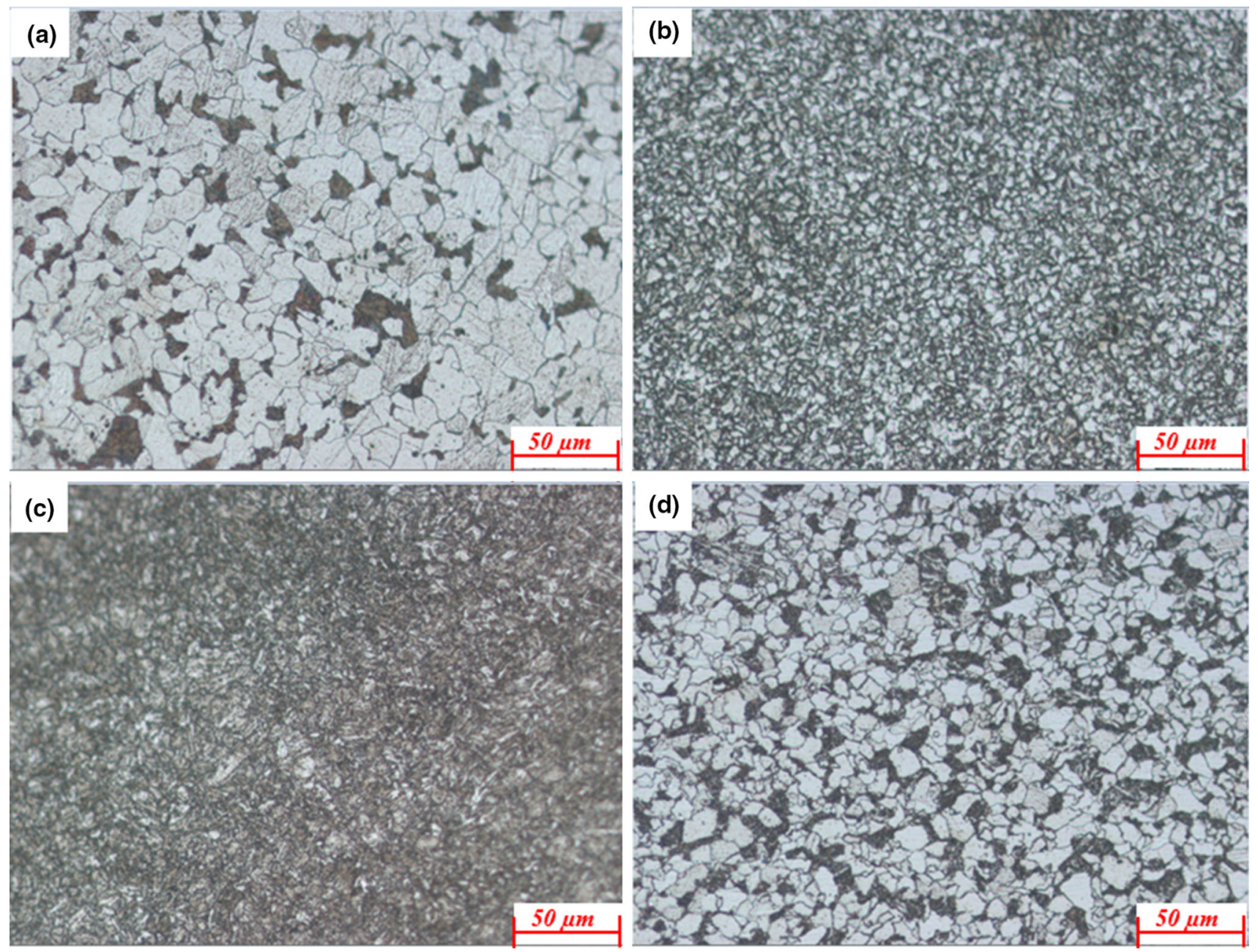

Fig. 1 Optical micrographs of as-received steels (a) Steel A, (b) Steel B and (c) Steel C and (d) X65 

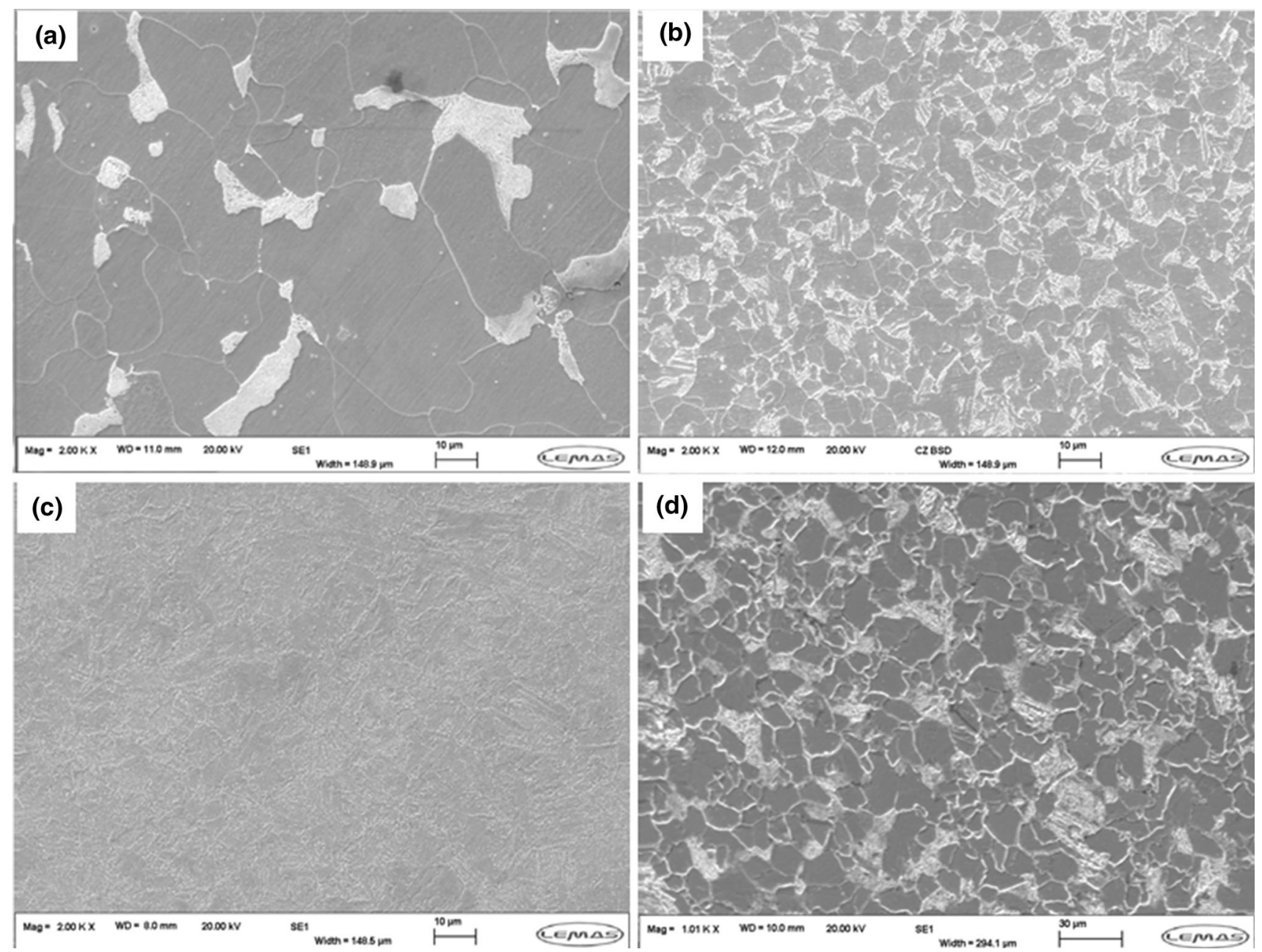

Fig. 2 SEM micrographs of as-received samples (a) Steel A, (b) Steel B and (c) Steel C and (d) X65

Steels A, B and X65 consist of light and dark zones which in the optical micrographs are ferrite and pearlite phases, respectively. In SEM micrographs, these zones are colonies of pearlite within the ferrite matrix. The lamellae structures of the pearlite phase are clearly visible in Fig. 2(a). Another distinctive feature of the micrographs of these three specimens is their grain (phase) sizes which within each sample are the same and uniformly distributed. However, the grain sizes of the steels differ from each other.

The difference in the grain size of these specimens is made more evident by Fiji-ImageJ analysis and ASTM grain size number computed according to ASTM E112-12 standard (Ref 36). These are shown in Table 3 . The small grain size numbers of the steels can be attributed to the presence of alloying elements such as $\mathrm{Nb}, \mathrm{Ti}$ and $\mathrm{V}$ which researchers (Ref 29, 37, 38) have observed are good grain refiners. The ferrite-pearlite ratio of Steels A, B and X65 can be ranked as Steel $\mathrm{B}<\mathrm{X} 65<$ Steel $\mathrm{A}$ as indicated in Table 3. This difference in microstructures and grain size is linked to the chemical composition of the steels (Ref 39, 40) and the thermomechanical processes involved in their production (Ref 10, 40, 41).

Steel A and X65 as indicated in Table 1 have the same chemical composition, but Fig. 1 and 2 showed that they have different microstructures. Similar cases have been reported in the literatures (Ref 40, 42, 43) where different microstructures were obtained from carbon steel with the same chemical composition and vice versa depending on heat treatment route. These authors have reported that the precipitation, volumetric fraction, uniformity and distribution of pearlite in carbon steels can be attributed to carbon content and thermo-mechanical processes (heat treatment routes). Ochoa et al. (Ref 40) obtained different microstructures of API 5L X42 using three different heat treatment routes with each of the microstructures exhibiting variant corrosion behavior in $\mathrm{CO}_{2}$ - saturated $0.5 \mathrm{M}$ $\mathrm{NaCl}$ solution. Asiful (Ref 43) through repeated quenching also impacted different microstructures on E34 micro-alloyed steel which showed different corrosion rates in 3.5 wt. $\% \mathrm{NaCl}$ solution. Thus, although Steel A and X65 have the same chemical composition (Table 1), their different microstructural behaviors (Fig. 2) could be linked to heat treatment processes used.

The optical and SEM micrographs of Steel C shown in Fig. 1(c) and 2(c), respectively, revealed bainitic structure with evenly distributed acicular ferrites (Ref 29). Literatures revealed that bainitic structures are formed when the decomposition of austenite to ferrite and pearlites is restrained by the presence of micro-alloying elements (Ref 29, 37, 41, 44, 45). Kermani and Morshed (Ref 46) and Kermani et al. (Ref 38) identified $\mathrm{Cr}$ and $\mathrm{Mo}$ as alloying elements that retard decomposition of martensite or austenite to ferrites and carbides. Steel $\mathrm{C}$ as shown in Table 1 contains more $\mathrm{Cr}(0.99$ wt.\%) and Mo 
Table 3 ASTM grain size number and ferrite/pearlite ratio (\%) for the samples

\begin{tabular}{lrrrr}
\hline Samples & A & X65 & B & C \\
\hline ASTM grain size no & 3.9 & 4.5 & 5.6 & 5.8 \\
Ferrite/pearlite, \% & 63.6 & 57.5 & 48.2 & \\
Average grain size, $\mu \mathrm{m}$ & 68.5 & 46.6 & 20.6 & 14.7 \\
\hline
\end{tabular}

(0.46 wt.\%) than the other steels. This could have necessitated its bainitic structure.

\subsection{Electrochemical Tests}

Linear polarization resistance (LPR) and Tafel extrapolation techniques were used to assess the corrosion behavior of the steels in both aerated and deaerated aqueous solutions of $\mathrm{NaCl}$ at ambient temperature. LPR was conducted for $6 \mathrm{~h}$, while the potentiodynamic polarization was performed after $6 \mathrm{~h}$ LPR. This is because LPR technique generally uses only minor perturbation around OCP $( \pm 15 \mathrm{mV}$ in this case $)$ and so does not significantly affect the surface of specimen. That is why it is used for assessing long time corrosion propensity of metals (Ref 47). Also, the alternating potential measurement helps to stabilize the OCP after each LPR scan. The solutions were stirred throughout the period of the tests. This was to ensure that the surface concentration of the species was approximately equal to the bulk concentration and thus minimizes the effect of diffusion polarization (Ref 47-50). Three different concentrations of $\mathrm{NaCl}$ namely $1.0,3.5$ and 10.0 wt.\% were used. For LPR measurements, the specimens were polarized within the range of $\pm 15 \mathrm{mV}$ versus OCP and at a scan rate of $0.25 \mathrm{mV} \mathrm{s}^{-1}$ for $6 \mathrm{~h}$. For the potentiodynamic polarization, the Tafel cathodic and anodic branches were scanned separately. However, the effective scan range for the two sweeps was $\pm 250 \mathrm{mV}$ versus OCP and at a scan rate of $0.5 \mathrm{mV} / \mathrm{s}$. The ohmic drop of the experimental setup was calculated to ensure it is too minute and so was neglected. This was achieved using Eq 5 as reported by Oelssner et al. (Ref 49)

$R_{U}=\frac{Z}{2 K A}$,

where $Z=$ the gap between the working electrode and the reference electrode $(\mathrm{mm}), K=$ the electrical conductivity of 3.5 wt. $\% \mathrm{NaCl}$ solution $(\mathrm{mS} / \mathrm{cm})$ (Ref 51$)$ and $A=$ the area of the working electrode $\left(\mathrm{mm}^{2}\right)$.

The estimated ohmic drop was about $0.1 \mu \Omega$. This is very negligible and hence was neglected in all the tests.

3.2.1 Linear Polarization Resistance Techniques. Figure 3 shows the plots of average LPR corrosion rate against time for the four specimens in three different concentrations (1.0, 3.5 and $10.0 \mathrm{wt} . \%)$ of aerated and deaerated $\mathrm{NaCl}$ solutions at ambient temperature and for $6 \mathrm{~h}$. It can be observed from Fig. 3(a-c) that the plots of corrosion rate versus time for all the four specimens in aerated media increased with time, but for steels in Fig. 3(c). This increase in corrosion rate according to Davis (Ref 52) and Taits (Ref 35) can be ascribed to the porosity of the air-formed oxide film on the surface of the specimens which could not protect the steels from corrosion. On the other hand, Fig. 3(d-f) showed decreasing corrosion rate with time for all the steels in the deaerated media. This signified that the dissolution of the air-formed oxide film on the surface of the specimens hindered increase in corrosion rate (Ref 35, 52). A closer observation of Fig. 3(d-f) shows that the corrosion rate of the steels in the deaerated solutions has begun to stabilize within the 6-h test. Vera et al. (Ref 29) and El Desouky and Aboeldahab (Ref 53) also attributed the decrease in corrosion rate to the formation of corrosion products on the surface of the specimens.

The plots of the average corrosion rate for the respective steels in $1.0,3.5$ and $10.0 \mathrm{wt} . \% \mathrm{NaCl}$ solutions at ambient temperature and for $6 \mathrm{~h}$ are compared in Fig. 4(a) aerated and 4(b) deaerated. These figures show that the corrosion attack for all the four specimens was more severe in $3.5 \mathrm{wt} . \% \mathrm{NaCl}$ solution for both aerated and deaerated solutions than in the other two concentrations (1.0 and $10.0 \mathrm{wt} . \%)$. This is in agreement with the reports of Yari (Ref 2) and Fang et al. (Ref 25 ). Dissolved oxygen (DO) as an electron acceptor (Ref 21$24)$ in redox reactions and a depolarizer ( Ref 23) accelerates the dissolution of metals in chloride environment. The witnessed decrease in corrosion rate with increase in $\mathrm{NaCl}$ concentration, according to Eliyan et al. (Ref 27), can also be attributed to the decrease in the solubility of oxygen with increase in $\mathrm{NaCl}$ concentration. Fang et al. (Ref 25) also reported that the adsorption of chloride on the surface of the steels contributed to the reduction in corrosion rate with increase in salt concentration.

The reports of these authors elucidate the decrease in corrosion rate in $10 \mathrm{wt} . \% \mathrm{NaCl}$ solution as shown in Fig. 4. However, the effect of oxygen content on the corrosion of steel in aqueous solution of $\mathrm{NaCl}$ has not been clearly understood as some authors presented divergence results. For instance, El Desouky and Aboeldahab (Ref 53) studied the effect of different concentration of $\mathrm{NaCl}(0.1-2 \mathrm{M})$ on maraging steel and reported a continuous increase in corrosion rate with increase in $\mathrm{NaCl}$ concentration. In agreement with El Desouky and Aboeldahab (Ref 53), Liu et al. (Ref 1) categorized the effect of chloride ion on corrosion of carbon steels as smooth invariant stage, slow rise stage and the rapid rise stage.

To further buttress the effect of $\mathrm{NaCl}$ concentration on the corrosion behavior of the steels, the corrosion rates in both media were plotted against $\mathrm{NaCl}$ concentrations as shown in Fig. 5. This figure clearly showed that the severity of corrosion attack was highest for all the steels in $3.5 \mathrm{wt} \% \%$ Nacl solution of both conditions. A sharp increase in corrosion rate can be observed as the concentration increased from $1.0 \mathrm{wt} . \% \mathrm{NaCl}$ to 3.5 wt. $\% \mathrm{NaCl}$, while a mild decrease was observed as $\mathrm{NaCl}$ concentration increased from 3.5 wt. $\% \mathrm{NaCl}$ to $10.0 \mathrm{wt} . \%$ Nacl. This is in corroboration with the profiles of the results shown in Fig. 4.

According to Han et al. (Ref 54), $\mathrm{NaCl}$ concentrations play three major roles in corrosion kinetics of carbon steels which include accelerating the corrosion process by forming intermediate corrosion species, decreasing the solution $\mathrm{pH}$ which also accelerates the corrosion process and reducing the solubility of 


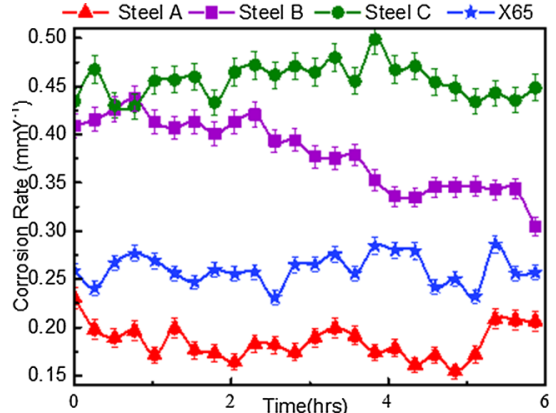

(a)

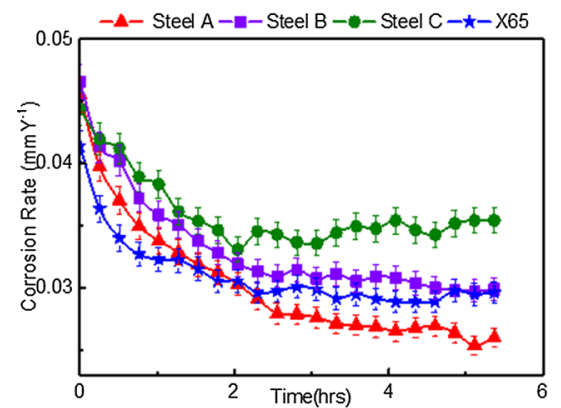

(d)

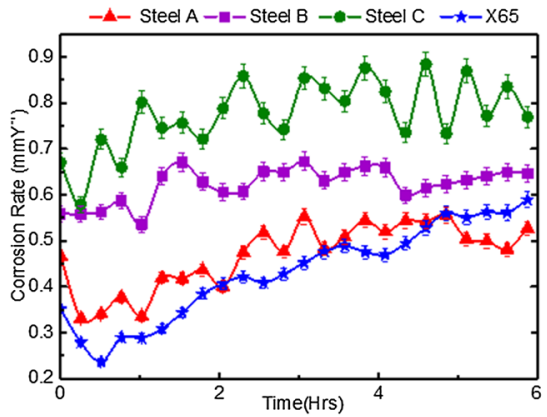

(b)

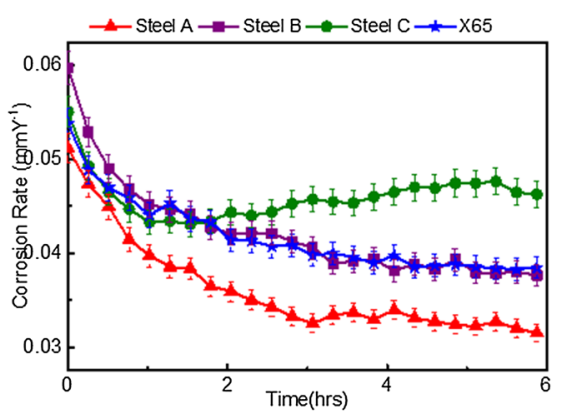

(e)

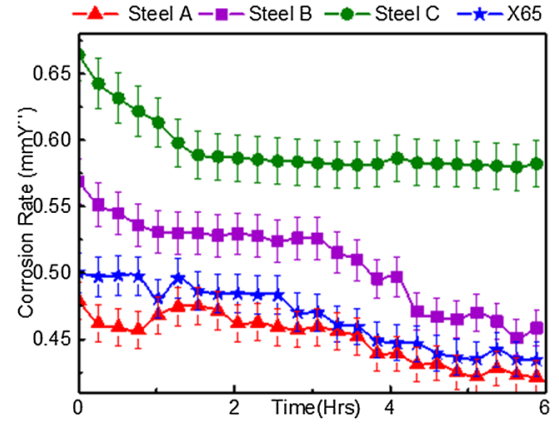

(c)

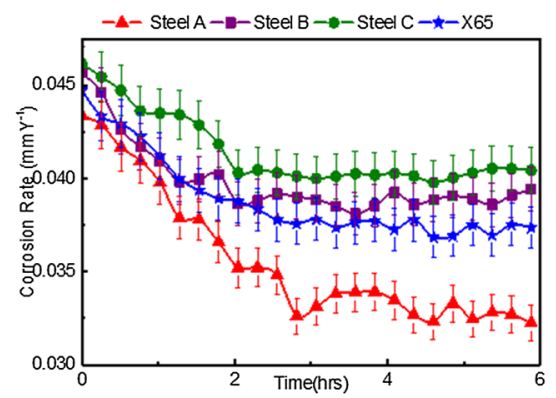

(f)

Fig. 3 Average LPR corrosion rates of the steels in aerated and deaerated brine solutions at ambient temperature and for 6 h: (a) 1.0 wt.\% aerated, (b) 3.5 wt.\% aerated, (c) $10.0 \mathrm{wt} . \%$ aerated, (d) 1 wt.\% deaerated, (e) $3.5 \mathrm{wt} . \%$ deaerated, (f) $10 \mathrm{wt} . \%$ deaerated
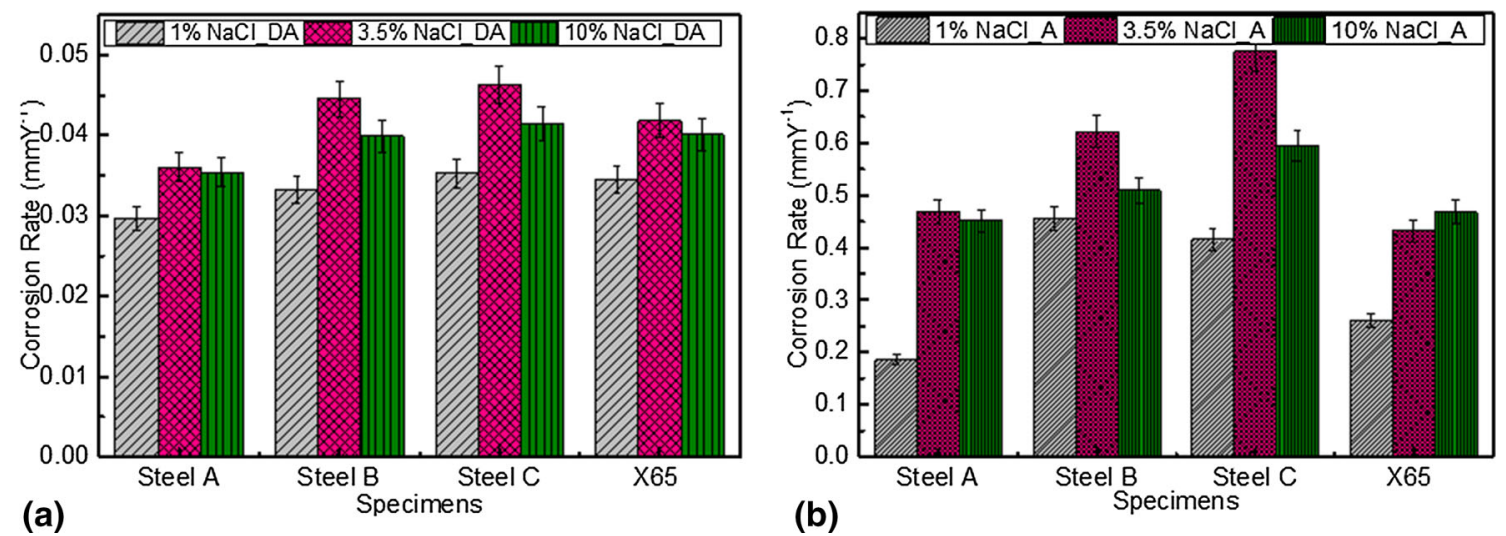

Fig. 4 Average LPR corrosion rates of steels in different concentration $\mathrm{NaCl}$ solutions: (a) deaerated and (b) aerated at ambient temperature and for $6 \mathrm{~h}$

the dissolved oxygen with the attendant decrease in corrosion rate. The net effect of increase in $\mathrm{NaCl}$ concentration is the reduction in corrosion rate. This means that the effect of reduction in DO solubility (salting out) dominates the other two competing effects. This was also reported by Yari (Ref 2$)$ that in a basic or neutral solution, oxygen reduction reaction is the predominant cathodic reaction in competition with the hydrogen evolution reaction. Caceres et al. (Ref 55) also reported that the major reaction governing corrosion in most practical oilfield application is the reduction reaction of oxygen present in solution. Vera et al. (Ref 29) summarized the electrochemical and chemical reactions that occur during metal dissolution in aqueous solutions as shown in Eq 6-11.
Anodic reaction: $\mathrm{Fe}_{(\mathrm{s})} \rightarrow \mathrm{Fe}_{(\mathrm{aq})}^{2+}+2 \mathrm{e}^{-}$

Cathodic reaction: $\mathrm{O}_{2(\mathrm{~g})}+2 \mathrm{H}_{2} \mathrm{O}_{(1)}+4 \mathrm{e}^{-} \rightarrow 4 \mathrm{OH}_{(\mathrm{aq})}^{-}$

Total reaction: $2 \mathrm{Fe}_{(\mathrm{s})}+\mathrm{O}_{2(\mathrm{~g})}+2 \mathrm{H}_{2} \mathrm{O}_{(\mathrm{l})} \rightarrow 2 \mathrm{Fe}_{(\mathrm{aq})}^{2+}+4 \mathrm{OH}_{(\mathrm{aq})}^{-}$

$$
\begin{aligned}
& \mathrm{Fe}_{(\mathrm{aq})}^{2+}+2 \mathrm{OH}_{(\mathrm{aq})}^{-} \rightarrow \mathrm{Fe}(\mathrm{OH})_{2(\mathrm{~s})} \\
& 4 \mathrm{Fe}(\mathrm{OH})_{3(\mathrm{~s})}+\mathrm{O}_{2(\mathrm{~g})}+2 \mathrm{H}_{2} \mathrm{O}_{(\mathrm{l})} \rightarrow 4 \mathrm{Fe}(\mathrm{OH})_{3(\mathrm{~s})}
\end{aligned}
$$




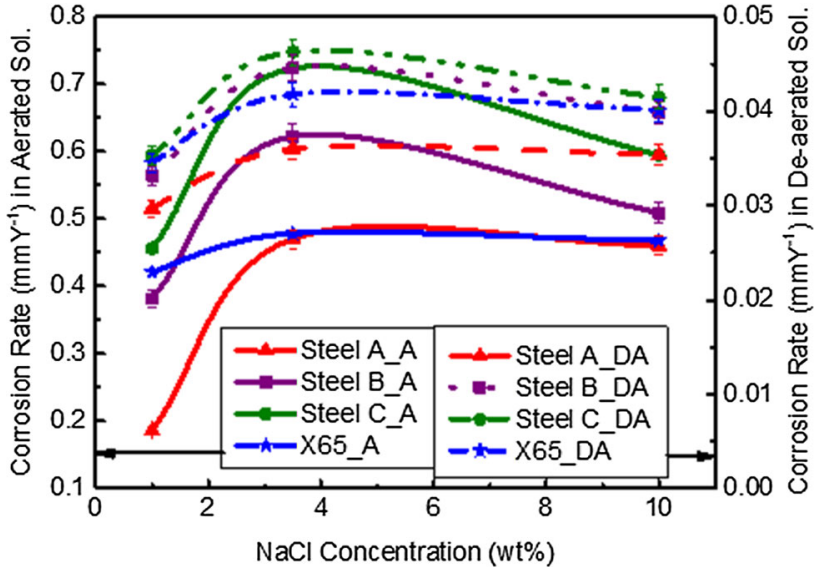

Fig. 5 Average LPR corrosion rates vs. aerated and deaerated $\mathrm{NaCl}$ concentration at ambient temperature and for $6 \mathrm{~h}$

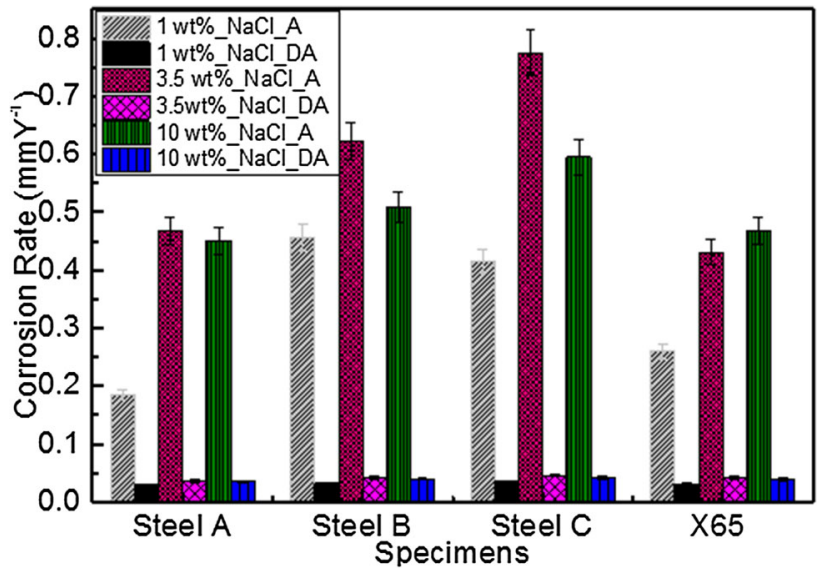

Fig. 6 Comparison of corrosion rates of steels in aerated and deaerated $\mathrm{NaCl}$ solutions at ambient temperature and for $6 \mathrm{~h}$

$2 \mathrm{Fe}(\mathrm{OH})_{3(\mathrm{~s})} \rightarrow \mathrm{Fe}_{2} \mathrm{O}_{3} \cdot \mathrm{H}_{2} \mathrm{O}_{(\mathrm{s})}+2 \mathrm{H}_{2} \mathrm{O}_{(\mathrm{l})}$

The results of this work also showed that the rate of corrosion of the specimens was more severe in aerated solutions than in deaerated solutions as is clearly shown in Fig. 6. This means that all the specimens exhibited higher susceptibility to corrosion attack in aerated solutions than in deaerated solutions. Many researchers (Ref 1, 2, 20, 21, 54-56) have observed similar results concerning the corrosion effect of dissolved oxygen in crude oil. The decrease in corrosion rate of the specimens in deaerated solutions when compared with the aerated solutions was about $89 \%$ in 1.0 wt. $\% \mathrm{NaCl}, 93 \%$ in 3.5 wt. $\% \mathrm{NaCl}$ and $92 \%$ in 10.0 wt. $\% \mathrm{NaCl}$. This is in agreement with the report of Jung et al. (Ref 21) who reported a decrease of $91 \%$ when the concentration of dissolved oxygen was decreased from 9 to $2 \mathrm{mg} / \mathrm{L}$.

The effect of dissolved oxygen (DO) on the corrosion of oil and gas facilities is significantly influenced by the presence of other components of crude oil streams. One of such components is chloride salts. Mameng et al. (Ref 56) investigated the effects of $\mathrm{pH}$ and oxygen on the corrosion resistance of carbon steel in highly concentrated sodium chloride and reported that oxygen content is an important factor influencing the corro-

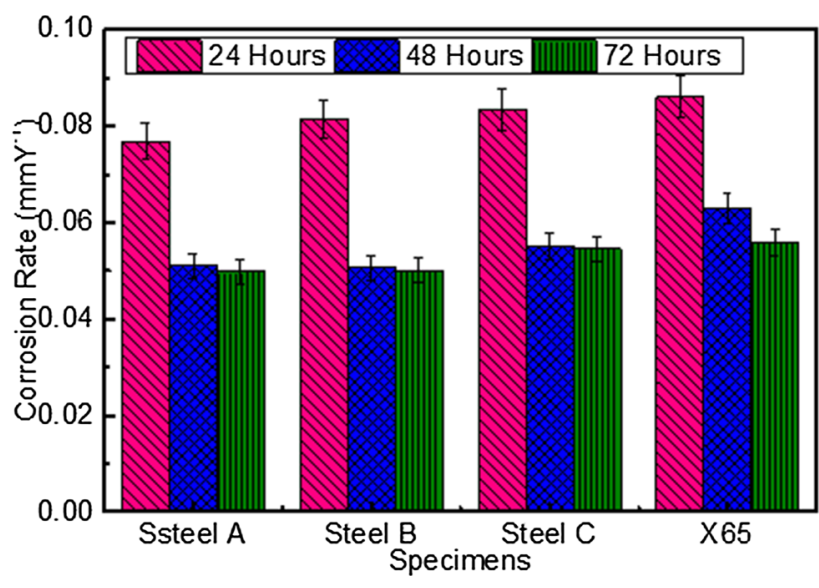

Fig. 7 Corrosion rate by weight loss of specimens in $3.5 \mathrm{wt} . \%$ $\mathrm{NaCl}$ at ambient temperature

siveness of sodium chloride solution with aerated condition being the most corrosive. This is attributed to the effect of sodium chloride concentration on the solubility of oxygen in aqueous solution, which is reported to be highest at $3.5 \mathrm{wt} . \%$ $\mathrm{NaCl}(\operatorname{Ref} 2,25)$.

3.2.2 Weight Loss. The results of the weight loss experiments are shown in Fig. 7. This figure revealed that there was a decrease in corrosion rate with immersion time. Like in the LPR experiments, this is due to the accumulation of corrosion products that partially block the surface of the steels with increase in immersion time (Ref 40, 57). The steels also exhibited the same trend of behavior as observed in the LPR experiments attesting to the fact that the corrosion rate of the steels with ferrite-pearlite microstructures is lower than the Steel C with bainitic structure (Ref 40, 58).

3.2.3 Potentiodynamic Polarization (Tafel Plots). Potentiodynamic polarization measurements were conducted in both aerated and deaerated $1.0 \mathrm{wt} . \% \mathrm{NaCl}, 3.5 \mathrm{wt} . \% \mathrm{NaCl}$ and 10.0 wt. $\% \mathrm{NaCl}$ at ambient temperature. Figure 8 shows the Tafel plots of the experiment in aerated and deaerated $3.5 \mathrm{wt} . \%$ $\mathrm{NaCl}$ solutions, respectively. The Tafel extrapolation parameters for all the steels in aerated and deaerated solution for the three $\mathrm{NaCl}$ concentrations are listed in Table 4

It can be observed from Fig. 8 that the anodic current increased continuously with increase in corrosion potentials for all the specimens in aerated and deaerated $3.5 \mathrm{wt} . \% \mathrm{NaCl}$ solutions. This signified a continuous dissolution of iron in agreement with the trend of the LPR results. Also, the anodic branches show sharp increase in slopes exhibiting well-defined Tafelian regions within the low over-potentials. This is an indication that passive films were not formed (Ref 40). The cathodic branch for all the steels in the aerated solutions showed a mixed charge and mass transfer control reactions depicting well-pronounced current plateaus. This can be ascribed to the mass-transport limitations of oxygen reduction reactions since reduction in dissolved oxygen as shown in Eq 1 is the dominant reaction in aerated conditions ( $\operatorname{Ref} 2,29,57)$. On the other hand, under deaerated condition, the cathodic reduction reaction shown in Eq 1 with a corresponding small rate of hydrogen evolution is the main reaction. This low hydrogen evolution resulted to the witnessed low corrosion rate. 

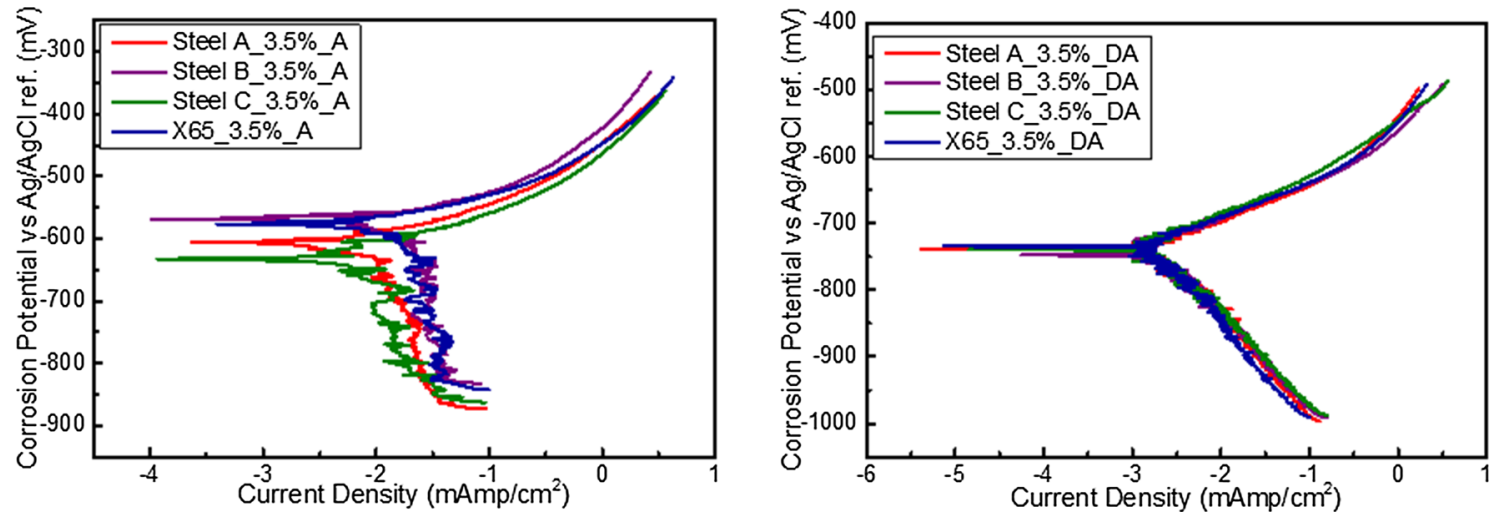

Fig. 8 Tafel plots of specimens in aerated and deaerated 3.5 wt.\% $\mathrm{NaCl}$ solutions at ambient temperature

Table 4 Tafel extrapolation parameters of the specimens in aerated and deaerated solutions of three NaCl concentrations

\begin{tabular}{|c|c|c|c|c|c|}
\hline $\mathrm{NaCl}(w t . \%)$ & Sample & $E_{\text {Corr }}, \mathbf{m V}$ & $i_{\text {Corr }}, \mu \mathrm{A} / \mathbf{c m}^{2}$ & $\beta_{a}, \mathrm{mV} / \mathrm{dec}$ & $\beta_{c}, \mathrm{mV} / \mathrm{dec}$ \\
\hline \multirow{4}{*}{ 1.0 Aerated } & Steel A & -637 & 6.00 & 38 & 145 \\
\hline & Steel B & -656 & 7.50 & 60 & 175 \\
\hline & Steel C & -502 & 11.00 & 38 & 120 \\
\hline & X65 & -611 & 6.50 & 65 & 120 \\
\hline \multirow[t]{4}{*}{ 1.0 Aerated } & Steel A & -733 & 1.19 & 54 & 94 \\
\hline & Steel B & -732 & 1.25 & 53 & 96 \\
\hline & Steel C & -726 & 1.37 & 57 & 122 \\
\hline & X65 & -730 & 1.22 & 49 & 105 \\
\hline \multirow{4}{*}{ 3.5 Aerated } & Steel A & -590 & 21.00 & 65 & 449 \\
\hline & Steel B & -591 & 24.00 & 69 & 411 \\
\hline & Steel C & -581 & 28.00 & 55 & 530 \\
\hline & X65 & -580 & 21.50 & 64 & 450 \\
\hline \multirow[t]{4}{*}{ 3.5 Deaerated } & Steel A & -742 & 1.40 & 53 & 99 \\
\hline & Steel B & -740 & 1.50 & 55 & 117 \\
\hline & Steel C & -738 & 1.60 & 55 & 108 \\
\hline & X65 & -738 & 1.40 & 53 & 111 \\
\hline \multirow[t]{4}{*}{ 10.0 Deaerated } & Steel A & -607 & 17.00 & 40 & 80 \\
\hline & Steel B & -634 & 20.00 & 65 & 265 \\
\hline & Steel C & -600 & 23.00 & 55 & 155 \\
\hline & X65 & -621 & 18.00 & 50 & 120 \\
\hline \multirow[t]{4}{*}{ 10.0 Deaerated } & Steel A & -758 & 0.90 & 54 & 86 \\
\hline & Steel B & -741 & 1.35 & 51 & 90 \\
\hline & Steel C & -742 & 1.4 & 56 & 101 \\
\hline & X65 & -731 & 1.16 & 40 & 64 \\
\hline
\end{tabular}

$\mathrm{O}_{2(\mathrm{~g})}+\mathrm{H}_{2} \mathrm{O}_{(\mathrm{l})}+4 \mathrm{e}^{-} \rightarrow 4 \mathrm{OH}_{(\mathrm{aq})}^{-}$

$2 \mathrm{H}_{2} \mathrm{O}_{(\mathrm{l})}+2 \mathrm{e}^{-} \rightarrow \mathrm{H}_{2(\mathrm{~g})}+2 \mathrm{OH}_{(\mathrm{aq})}^{-}$

The Tafel plots for other environmental conditions (aerated 1 and $10.0 \mathrm{wt} \%$ and deaerated 1.0 and $10.0 \mathrm{wt} . \%$ ) displayed similar profiles, but with a mild current plateaus in the deaerated solutions which is due to virtually absence of DO.

The Tafel plots of the experiments in aerated and deaerated 1.0 wt. $\% \mathrm{NaCl}, 3.5$ wt. $\% \mathrm{NaCl}$ and 10.0 wt. $\% \mathrm{NaCl}$ solutions shown in Fig. 9 vividly revealed that the corrosion current density in aerated media is more than in the deaerated media. This is in corroboration with the results of LPR experiments and with the report of Jung (Ref 21).

It is evident from Fig. 9 and Table 4 that there was a cathodic shift (i.e., in the negative direction), which for Steel A (for instance) increased from $-607 \mathrm{mV}$ in aerated $10 \% \mathrm{NaCl}$ solution to $-758 \mathrm{mV}$ in deaerated $10 \% \mathrm{NaCl}$ solution. This cathodic shift in corrosion potential is an indication that the corrosion process was mainly accelerated by cathodic reactions (Ref 59). This gave a corresponding decrease in corrosion current density from $17 \mu \mathrm{A} \mathrm{cm}{ }^{-2}$ in the aerated solutions to $0.9 \mu \mathrm{A} \mathrm{cm}^{-2}$ in the deaerated solutions of Steel A. These values are comparable with the report of other authors (Ref 3 , $30,31)$. Since corrosion current density $i_{\text {Corr }}$ is proportionally related to corrosion rate (CR) (Ref 59, 60) and from the values of $i_{\text {Corr }}$ in Tables 4 , the corrosion rates of the steels in both aerated and deaerated solutions can be ranked as $\mathrm{CR}_{\text {SteelA }}<\mathrm{CR}_{\mathrm{X} 65}<\mathrm{CR}_{\text {SteelB }}<\mathrm{CR}_{\text {SteelC }}$. This trend of corrosion rate corroborated the linear polarization resistance results and can be attributed to the chemical compositions and microstructures of the samples.

Figure 10 shows the SEM micrographs of the specimens corroded in aerated and deaerated 1 wt. $\% \mathrm{NaCl}$. A closer 

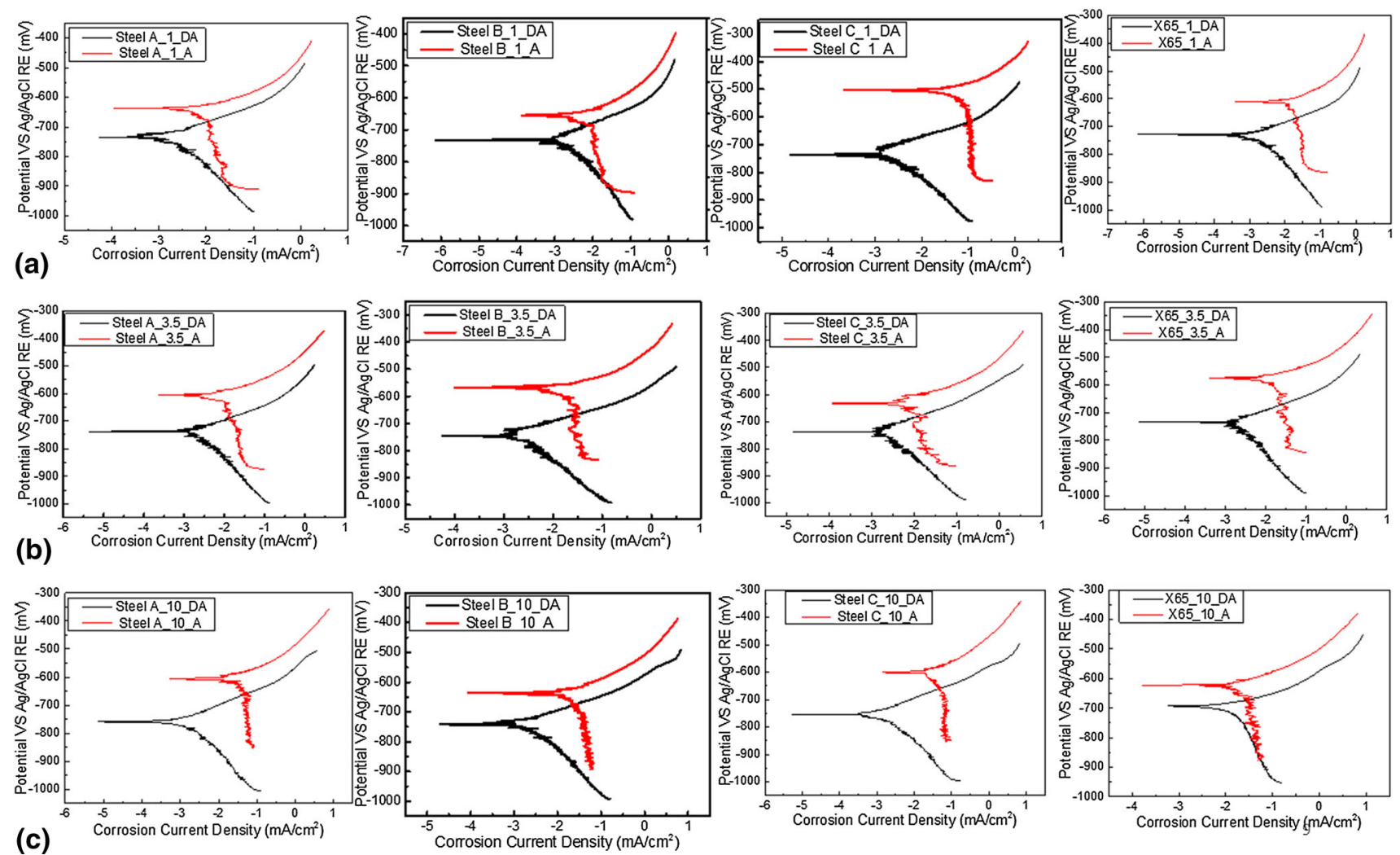

Fig. 9 Comparison of Tafel plots of specimens in aerated (a) and deaerated (DA) (a) 1 wt.\% NaCl, (b) 3.5 wt. $\% \mathrm{NaCl}$ and (c) $10 \mathrm{wt} . \% \mathrm{NaCl}$ solutions
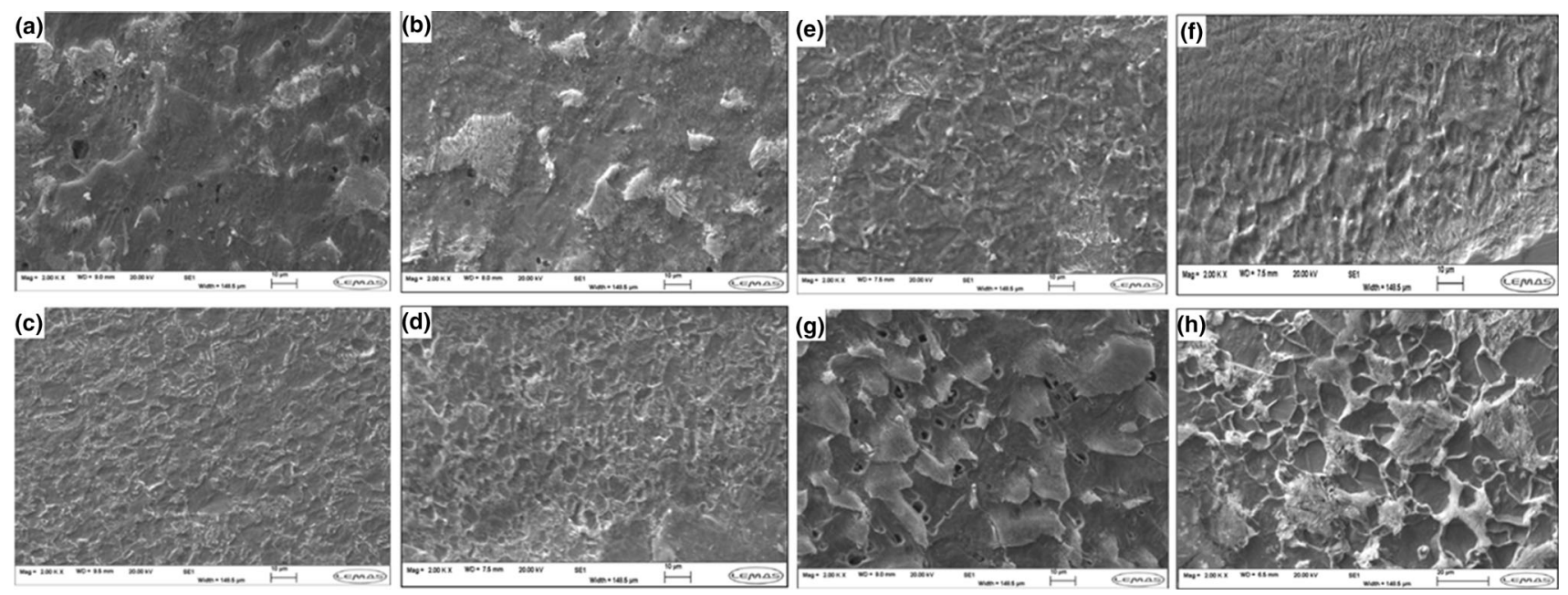

Fig. 10 SEM micrographs of the samples corroded in 1 wt.\% aerated and deaerated brine solutions at ambient temperature: (a) Steel A in aerated, (b) Steel A in deaerated, (c) Steel B in aerated, (d) Steel B in deaerated, (e) Steel C in aerated, (f) Steel C in deaerated, (g) X65 in aerated, (h) X65 in deaerated

examination of this figure showed that the steels corroded in aerated condition exhibited more severe attack than those corroded in deaerated solution as reported by Jung et al. (Ref 21).The presence, amount and distribution of various microstructural phases have considerable influence on the corrosion behavior of steels offering significant protective and adherent properties to the corrosion product. The variation in pearlite/ferrite ratio and the grain size of the specimens shown in Table 2 could have contributed to the witnessed trend in corrosion rate. Figure 2 reveals that Steels A and X65 have ferrite-pearlite microstructures with Steel A having more ferritic phase and larger grain size (Table 3). On the other hand, X65 has more pearlites and smaller grain sizes.

This difference in microstructure is dependent on the chemical composition and the thermo-mechanical processes involved in production. This has been reported in the literatures (Ref 40, 42) that carbon steels with the same chemical composition can exhibit different microstructures and vice 
versa depending on heat treatment route. This can significantly affect the corrosion behavior (protective and adherent properties of corrosion film) of carbon steel. When a freshly polished carbon and low-alloyed steel with ferrite-pearlite microstructures is immersed in an electrolyte, selective dissolution of the ferrite phase takes place leaving the pearlite unaffected. The undissolved pearlite forms cementite platelets. The adherence and protectiveness of the corrosion product film is related to the presence of these cementite platelets which strengthen and anchor the films to the metal substrate (Ref 42, 45). Some authors (Ref 32, 41, 42, 61) have also reported that cementite acts as cathode, while the ferrite acts as the anode in ferritepearlite microstructures. It follows that the specimen with higher cathode-anode (pearlite-ferrite) ratio should be more susceptible to corrosion attack (Ref 23, 24, 60). Pearlite phase has also been observed to increase with carbon content (Ref 62, 63). Therefore, the specimen with higher carbon content has more pearlite phase and consequently greater cathode to anode ratio resulting in higher corrosion rate. This phenomenon was exhibited by the three steels with ferrite-pearlite microstructures (Steels A, B and X65) used in this work.

Another distinctive characteristic of these micro-alloyed steels is their grain size as shown in Table 3. Asiful et al. (Ref 43) noted that small grain microstructures have more surface area and so are more prone to corrosion attack. It then means that the combine effect of these two factors (cathode-anode ratio and grain size) majorly contributed to Steel A exhibiting a better corrosion performance than X65. Thus, although Steel A and X65 have the same chemical composition (Table 1), their different microstructural behaviors (Fig. 2) could be due to heat treatment processes used. This in turn contributed to the witnessed variation in their corrosion performance. Steel B also consist of ferrite-pearlite phase with finer grain size and globular structure leading to porous and flaky corrosion film with poor adhesion as shown in Fig. 10(c) and (d) and hence exhibiting a much lower corrosion resistance than Steel A and X65. This corroborated the report of Islam and Farhat (Ref 22). The protruding laminar cementite can be clearly seen in Fig. 10 for steels A (Fig. 10a and b) and X65 (Fig. 10g and h), suggesting that the ferrite phases have suffered dissolution, while the cementite appeared unaffected (Ref 64).

Steel $\mathrm{C}$ consists of bainitic structures with dispersed acicular ferrite. This formed a sludge-like corrosion product which according to Zhao (Ref 39) renders the specimen unprotected against corrosion attack. These sludge-like corrosion products allow the ingress of corrosion species to the substrate leading to severe corrosion spallation (Ref 64) as shown in Fig. 10(e) and (f). Steel $\mathrm{C}$ also has high $\mathrm{Cr}$ and Mo content. These elements improve corrosion resistance by favoring passivity (Ref 29, 38, 41, 46, 65). Kermani et al. (Ref 38) and Kermani and Morshed (Ref 46) observed that an optimum $\mathrm{Cr}$ content, which is subjected to other alloying constituents and heat treatment, had a significant beneficial role on the $\mathrm{CO}_{2}$ corrosion performance of the steels. Ueda et al. (Ref 65) showed that below $60{ }^{\circ} \mathrm{C}$, the effect of $\mathrm{Cr}$ addition in enhancing corrosion performance was effective with $\mathrm{Cr}$ content more than 1 wt.\%. Other authors (Ref $62,63)$ have equally reported that the corrosion resistance of carbon steels deceases with increasing carbon content. It then means that due to high carbon content and low $\mathrm{Cr}$ content ( $<1$ wt.\%), the effect of $\mathrm{Cr}$ in enhancing corrosion performance of steel $\mathrm{C}$ was not pronounced. This is because the high carbon content formed carbides with $\mathrm{Cr}$ (Ref 38, 66-68) leading to increased cathodic site and therefore increased corrosion rate (Ref 29, 41).

The work of Kermani et al. (Ref 38) also showed that vanadium (V) had a major beneficial effect in reducing corrosion rate and that $\mathrm{V}$ in the excess of $50 \%$ stoichiometric ratio of carbon is needed to obtain the best combination of corrosion resistance. Thus, using simple charge/mass balance calculation, only about 0.005 wt. $\% \mathrm{C}$ is required to precipitate as carbide with the available $\mathrm{V}$ in Steel $\mathrm{C}$ (Table 1). Consequently, the excess/balance $\mathrm{C}$ content will precipitate with $\mathrm{Cr}$ as chromium carbide. This also contributed to increased corrosion rate of Steel $\mathrm{C}$.

\section{Conclusion}

The corrosion behavior of three fairly new generation steels in the family of micro-alloyed steel with varying chemical compositions and microstructures and whose corrosion characteristics have not been properly understood were compared with API 5L X65 carbon steel in different concentrations of aerated and deaerated brine solutions using linear polarization resistance, potentiodynamic polarization and weight loss techniques. The corrosion products on the surface of the steels were characterized using SEM/EDAX analysis. From the results of the experiments, the following conclusions can be drawn:

The three fairly new class of micro-alloyed steels exhibited comparable corrosion properties of micro-alloyed steels having presented similar corrosion characteristics with the reference specimen (API 5L X65). The potentiodynamic polarization plots of these steels showed a well-defined anodic Tafel region, but the cathodic behavior indicated a mixed charge and mass transfer control reactions with a more pronounced limiting current plateaus in the aerated solution. This was ascribed to the mass-transport limitations of oxygen reduction reactions occasioned by the presence of dissolved oxygen in the aerated solutions leading to about $80 \%$ higher corrosion rate than in the deaerated solutions. The corrosion rate of these proprietary steels increased with increase in $\mathrm{NaCl}$ concentration displaying a threshold in 3.5 wt. $\% \mathrm{NaCl}$ solutions due to decrease in the solubility of oxygen (salting out) and the adsorption of chloride on the surface of the steels. Also, the specimens demonstrated variations in corrosion rate which was linked to their chemical composition and microstructures whereby the specimens with ferrite-pearlite microstructures as well as smaller grain size and less carbon content presented better corrosion resistance in both aerated and deaerated solutions. In general, the results of the various corrosion techniques and the surface analysis employed corroborated each other and showed that the corrosion rate (CR) of the specimens can be ranked as $\mathrm{CR}_{\text {SteelA }}<\mathrm{CR}_{\mathrm{X} 65}<$ $\mathrm{CR}_{\text {SteelB }}<\mathrm{CR}_{\text {SteelC }}$. Thus, within the limit of experimental error, only Steel A showed a better corrosion performance than the reference specimen (API 5L X65).

\section{Acknowledgment}

We wish to acknowledge and appreciate the sponsorship of this work by Petroleum Technology Development Fund (PTDF), Abuja, Nigeria. For supplying the micro-alloyed steels used in this work, we say thank you to Professor B. Kermani. 


\section{Open Access}

This article is distributed under the terms of the Creative Commons Attribution 4.0 International License (http://creativecommons. org/licenses/by/4.0/), which permits unrestricted use, distribution, and reproduction in any medium, provided you give appropriate credit to the original author(s) and the source, provide a link to the Creative Commons license, and indicate if changes were made.

\section{References}

1. Y. Liu, B. Zhang, Y. Zhang, L. Ma, and P. Yang, Electrochemical Polarization Study on Crude Oil Pipeline Corrosion by the Produced Water with High Salinity, Eng. Fail. Anal., 2016, 60, p 307-315

2. M. Yari, An Intro to Pipeline Corrosion in Seawater, CorrosionPedia. Accessed 01 Dec 2015

3. M. Ilman, Analysis of Internal Corrosion in Subsea Oil Pipeline, Case Stud. Eng. Fail. Anal., 2014, 2, p 1-8

4. H. Tawancy, L.M. Al-Hadhrami, and F. Al-Yousef, Analysis of Corroded Elbow Section of Carbon Steel Piping System of an Oil-Gas Separator Vessel, Case Stud. Eng. Fail. Anal., 2013, 1, p 6-14

5. H. Moller, E. Boshoff, and H. Froneman, The Corrosion Behaviour of a Low Carbon Steel in Natural and Synthetic Seawaters, J. S. Afr Inst. Min. Metall., 2006, 106, p 585

6. M.A. Green, L. Deaton, and C.J. Lazzara, Cathodic Disbondment Testing Comparison of Carbon Fiber, Fiberglass, and Hybrid Composite Repair Systems for Pipelines, 2012 9th International Pipeline Conference, American Society of Mechanical Engineers, 2012, pp. $577-584$

7. S. Verhulst, L. Fuentes, J.O. Jirsa, D. Fowler, H. Wheat, and T. Moon, Evaluation and Performance Monitoring of Corrosion Protection by Fiber-Reinforced Composite Wrapping, Center for Transportation Research Report 0-1774-1 (2001)

8. T. Yoshida, J. Kato, M. Ito, S. Nishimura, and K. Kashima, Development of Corrosion-Resistant Steels and Their Application to Crude Oil Tankers, Nippon Steel \& Sumitomo Metal Corporation (2013)

9. B.D. Craig and L. Smith, Corrosion Resistant Alloys (CRAs) in the Oil and Gas Industry: Selection Guidelines Update; Nickel Institute Technical Series No. 10073 (2011)

10. D.A. Lopez, S. Simison, and S. De Sanchez, The Influence of Steel Microstructure on $\mathrm{CO}_{2}$ Corrosion. EIS Studies on the Inhibition Efficiency of Benzimidazole, Electrochim. Acta, 2003, 48, p 845-854

11. Y. Ren and C. Zeng, Corrosion Protection of 304 Stainless Steel Bipolar Plates Using TiC Films Produced by High-Energy Micro-Arc Alloying Process, J. Power Sour., 2007, 171, p 778-782

12. F. Varela, M. Tan, and M. Forsyth, An Electrochemical Method for Measuring Localized Corrosion Under Cathodic Protection, ECS Electrochem. Lett., 2015, 4, p C1-C4

13. M. Zheludkevich, K. Yasakau, A. Bastos, O. Karavai, and M. Ferreira, On the Application of Electrochemical Impedance Spectroscopy to Study the Self-Healing Properties of Protective Coatings, Electrochem. Commun., 2007, 9, p 2622-2628

14. E. Härkönen, B. Díaz, J. Światowska, V. Maurice, A. Seyeux, M. Vehkamäki, T. Sajavaara, M. Fenker, P. Marcus, and M. Ritala, Corrosion Protection of Steel with Oxide Nanolaminates Grown by Atomic Layer Deposition, J. Electrochem. Soc., 2011, 158, p C369-C378

15. J. Perry, A. Neville, V. Wilson, and T. Hodgkiess, Assessment of the Corrosion Rates and Mechanisms of a WC-Co-Cr HVOF Coating in Static and Liquid-Solid Impingement Saline Environments, Surf. Coat. Technol., 2001, 137, p 43-51

16. D. Toma, W. Brandl, and G. Marginean, Wear and Corrosion Behaviour of Thermally Sprayed Cermet Coatings, Surf. Coat. Technol., 2001, 138, p 149-158

17. L. Jianguo, G. Gaoping, and Y. Chuanwei, EIS Study of Corrosion Behaviour of Organic Coating/Dacromet Composite Systems, Electrochim. Acta, 2005, 50, p 3320-3332

18. Y.-S. Choi, J.-J. Shim, and J.-G. Kim, Corrosion Behavior of Low Alloy Steels Containing Cr, Co and $\mathrm{W}$ in Synthetic Potable Water, Mater. Sci. Eng. A, 2004, 385, p 148-156
19. Y.-S. Choi, J.-J. Shim, and J.-G. Kim, Effects of $\mathrm{Cr}, \mathrm{Cu}$, Ni and $\mathrm{Ca}$ on the Corrosion Behavior of Low Carbon Steel in Synthetic Tap Water, $J$. Alloys Compd., 2005, 391, p 162-169

20. A. Ismail and N. Adan, Effect of Oxygen Concentration on Corrosion Rate of Carbon Steel in Seawater, Am. J. Eng. Res, 2014, 3, p 64-67

21. H. Jung, U. Kim, G. Seo, H. Lee, and C. Lee, Effect of Dissolved Oxygen (DO) on Internal Corrosion of Water Pipes, Environ. Eng. Res., 2009, 14, p 195-199

22. M.A. Islam and Z.N. Farhat, Characterization of the Corrosion Layer on Pipeline Steel in Sweet Environment, J. Mater. Eng. Perform., 2015, 24, p 3142-3158

23. G.V. Chilingar, R. Mourhatch, and G.D. Al-Qahtani, The Fundamentals of Corrosion and Scaling for Petroleum \& Environmental Engineers: A Handbook for Petroleum and Environmental Engineers, Gulf Punlishing Company, Doha, 2013

24. L.T. Popoola, A.S. Grema, G.K. Latinwo, B. Gutti, and A.S. Balogun, Corrosion Problems During Oil and Gas Production and its Mitigation, Int. J. Ind. Chem., 2013, 4, p 1-15

25. H. Fang, B. Brown, and S. Nešic, Sodium Chloride Concentration Effects on General $\mathrm{CO}_{2}$ Corrosion Mechanisms, Corrosion, 2013, 69, p 297-302

26. H. Fang, S. Nesic, B.N. Brown, and S. Wang, General $\mathrm{CO}_{2}$ Corrosion in High Salinity Brines, Corrosion Conference, NACE International (2006)

27. F.F. Eliyan, F. Mohammadi, and A. Alfantazi, An Electrochemical Investigation on the Effect of the Chloride Content on $\mathrm{CO}_{2}$ Corrosion of API-X100 Steel, Corros. Sci., 2012, 64, p 37-43

28. X. Jiang, S. Nešic, B. Kinsella, B. Brown, and D. Young, Electrochemical Investigation of the Role of Cl-on Localized Carbon Dioxide Corrosion Behavior of Mild Steel, Corrosion, 2012, 69, p 15-24

29. R. Vera, F. Vinciguerra, and M. Bagnara, Comparative Study of the Behavior of API, 5L-X65 Grade Steel and ASTM A53-B Grade Steel against Corrosion in Seawater, Int. J. Electrochem. Sci., 2015, 10, p 6187-6198

30. E.-S.M. Sherif, A Comparative Study on the Electrochemical Corrosion Behavior of Iron and X-65 Steel in 4.0 wt.\% Sodium Chloride Solution After Different Exposure Intervals, Molecules, 2014, 19, p 9962-9974

31. E.-S.M. Sherif, A.A. Almajid, K.A. Khalil, H. Junaedi, and F.H. Latief, Electrochemical Studies on the Corrosion Behavior of API, X65 Pipeline Steel in Chloride Solutions, Int. J. Electrochem. Sci., 2013, 8, p $9360-9370$

32. S. Nešić, Key Issues Related to Modelling of Internal Corrosion of Oil and Gas Pipelines-A Review, Corros. Sci., 2007, 49, p 4308-4338

33. S. Nesic, J. Postlethwaite, and S. Olsen, An Electrochemical Model for Prediction of Corrosion of Mild Steel in Aqueous Carbon Dioxide Solutions, Corrosion, 1996, 52, p 280-294

34. A. G102-89, Standard Practice for Calculation of Corrosion Rates and Related Information from Electrochemical Measurements, ASTM International West Conshohocken, Pa. (1999)

35. W.S. Tait, An introduction to electrochemical corrosion testing for practicing engineers and scientists, Clair, Racine, Wis, 1994

36. A. E-112, Standard Test Methods for Determining Average Grain Size, ASTM International USA (2010)

37. W. Morrison, Overview of Microalloying in Steel, The Proceedings of the Vanitec Symposium, Guilin, China, pp. 25-35 (2000)

38. B. Kermani, M. Dougan, J.C. Gonzalez, C. Linne, and R. Cochrane, Development of Low Carbon Cr-Mo Steels with Exceptional Corrosion Resistance for Oilfield Applications, Corrosion Conference, NACE International, Paper No. 01065 (2001)

39. Y. Zhao, S. Yang, C. Shang, X. Wang, W. Liu, and X. He, The Mechanical Properties and Corrosion Behaviors of Ultra-Low Carbon Microalloying Steel, Mater. Sci. Eng. A, 2007, 454, p 695-700

40. N. Ochoa, C. Vega, N. Pébère, J. Lacaze, and J.L. Brito, $\mathrm{CO}_{2}$ Corrosion Resistance of Carbon Steel in Relation with Microstructure Changes, Mater. Chem. Phys., 2015, 156, p 198-205

41. S. Al-Hassan, B. Mishra, D. Olson, and M. Salama, Effect of Microstructure on Corrosion of Steels in Aqueous Solutions Containing Carbon Dioxide, Corrosion, 1998, 54, p 480-491

42. D. Lopez, T. Perez, and S. Simison, The Influence of Microstructure and Chemical Composition of Carbon and Low Alloy Steels in $\mathrm{CO}_{2}$ Corrosion. A State-of-the-Art Appraisal, Mater. Des., 2003, 24, p 561575 
43. A.H. Seikh, Influence of Heat Treatment on the Corrosion of Microalloyed Steel in Sodium Chloride Solution, J. Chem., 2013, doi: $10.1155 / 2013 / 587514$

44. D. Matlock and J. Speer, Microalloying Concepts and Application in Long Products, Mater. Sci. Technol., 2009, 25, p 1118-1125

45. C. Palacios and J. Shadley, Characteristics of Corrosion Scales on Steels in a $\mathrm{CO}_{2}$-Saturated $\mathrm{NaCl}$ Brine, Corrosion, 1991, 47, p 122-127

46. M. Kermani and A. Morshed, Carbon Dioxide Corrosion in Oil and Gas Production-A Compendium, Corrosion, 2003, 59, p 659-683

47. Printon Applied Research, Electrochemistry and Corrosion: Overview and Techniques, Princeton Applied Research, 801 S. Illinois Avenue, Oak Ridge, TN 37830. Accessed 07 Sept 2017

48. G. Walter, Problems Arising in the Determination of Accurate Corrosion Rates from Polarization Resistance Measurements, Corros. Sci., 1977, 17, p 983-993

49. J.R. Scully, Polarization Resistance Method for Determination of Instantaneous Corrosion Rates, Corrosion, 2000, 56, p 199-218

50. W. Oelssner, F. Berthold, and U. Guth, The iR Drop-Well-Known But Often Underestimated in Electrochemical Polarization Measurements and Corrosion Testing, Mater. Corros., 2006, 57, p 455-466

51. S. Nesic, N. Thevenot, J.L. Crolet, D. Drazic, Electrochemical Properties of Iron Dissolution in the Presence of $\mathrm{CO}_{2}$-Basics Revisited, Corrosion Conference, NACE International, Paper No. 3 (1996)

52. R.C. Weast, M.J. Astle, and W.H. Beyer, CRC Handbook of Chemistry and Physics, CRC Press, Boca Raton, 1988

53. J.R. Davis, Corrosion: Understanding the Basics, ASM International, Materials Park, 2000

54. H. El Desouky and H.A. Aboeldahab, Effect of Chloride Concentration on the Corrosion Rate of Maraging Steel, Open J. Phys. Chem., 2014, 4, p 147

55. J. Han, J.W. Carey, and J. Zhang, Effect of Sodium Chloride on Corrosion of Mild Steel in $\mathrm{CO}_{2}$-Saturated Brines, J. Appl. Electrochem., 2011, 41, p 741-749

56. L. Cáceres, T. Vargas, and L. Herrera, Influence of Pitting and Iron Oxide Formation During Corrosion of Carbon Steel in Unbuffered NaCl Solutions, Corros. Sci., 2009, 51, p 971-978

57. S.H. Mameng, A. Bergquist, and E. Johansson, Corrosion of Stainless Steel in Sodium Chloride Brine Solutions, A Corrosion Management and Applications Engineering Magazine; Outokumpu, acom vol. 2 (2014)

58. M. Henriquez, N. Pébère, N. Ochoa, and A. Viloria, Electrochemical Investigation of the Corrosion Behavior of API, 5L-X65 Carbon Steel in Carbon Dioxide Medium, Corrosion, 2013, 69, p 1171-1179

59. Q. Wu, Z. Zhang, X. Dong, and J. Yang, Corrosion Behavior of LowAlloy Steel Containing 1\% Chromium in $\mathrm{CO}_{2}$ Environments, Corros. Sci., 2013, 75, p 400-408

60. Z. Yin, X. Wang, R. Gao, S. Zhang, and Z. Bai, Electrochemical Behavior and Mechanism of $\mathrm{CO}_{2}$ Corrosion on P110 Steel in Simulated Oilfield Solution, Anti-Corros. Methods Mater, 2011, 58, p 227-233

61. P. Sarkar, P. Kumar, M.K. Manna, and P. Chakraborti, Microstructural Influence on the Electrochemical Corrosion Behaviour of Dual-Phase Steels in 3.5\% NaCl Solution, Mater. Lett., 2005, 59, p 2488-2491

62. T. Tanupabrungsun, B. Brown, S. Nesic, Effect of $\mathrm{pH}$ on $\mathrm{CO}_{2}$ Corrosion of Mild Steel at Elevated Temperatures, Corrosion Conference \& Expo, NACE International, Ohio University, Paper No. 2348 (2013)

63. D.V. Edmonds and R.C. Cochrane, The Effect of Alloying on the Resistance of Carbon Steel for Oilfield Applications to $\mathrm{CO}_{2}$ Corrosion, Mater. Res., 2005, 8, p 377-385

64. J. Guo, S. Yang, C. Shang, Y. Wang, and X. He, Influence of Carbon Content and Microstructure on Corrosion Behaviour of Low Alloy Steels in a $\mathrm{Cl}^{-}$Containing Environment, Corros. Sci., 2009, 51, p 242-251

65. S. Wu, Z. Cui, F. He, Z. Bai, S. Zhu, and X. Yang, Characterization of the Surface Film Formed from Carbon Dioxide Corrosion on N80 Steel, Mater. Lett., 2004, 58, p 1076-1081

66. M. Ueda, H. Takabe, and P.I. Nice, The Development and Implementation of a New Alloyed Steel for Oil and Gas Production Wells, Corrosion Conference, NACE International, Paper No. 00154 (2000)

67. E. David, C. Robert, and G. Rosa, Effect of Microalloying, Principally With Vanadium, Processing Conditions and Microstructure on Resistance to $\mathrm{CO}_{2}$ Corrosion, J. Iron Steel Res. (International), 2011, 18, p 183-191

68. A. Dugstad, H. Hemmer, and M. Seiersten, Effect of Steel Microstructure on Corrosion Rate and Protective Iron Carbonate Film Formation, Corrosion, 2001, 57, p 369-378 